Отримано: 5 травня 2021 р.

Прорецензовано: 23 квітня 2021 р.

Прийнято до друку: 23 квітня 2021 р.

e-mail: Ollena22@hotmail.com

DOI: $10.25264 / 2415-7384-2021-13-68-75$
Tyron O. M. How to use writers' pieces of art - popularizers of science and technology for the development of soft skills of engineering students. Наукові записки Національного університету "Острозька академія». Серія «Психологія» : науковий журнал. Острог : Вид-во НаУОА, червень 2021. № 13. С. 68-75.

\author{
Olena M. Tyron, \\ Associate Professor, \\ State University of Infrastructure and Technologies
}

\title{
HOW TO USE WRITERS' PIECES OF ART - POPULARIZERS OF SCIENCE AND TECHNOLOGY FOR THE DEVELOPMENT OF SOFT SKILLS OF ENGINEERING STUDENTS
}

Fiction writers who are engaged in science is a phenomenon. We studied this phenomenon to gain new opportunities for the development of soft skills in students of technical specialties and to widen the possibility of popularizing scientific achievements.

The chronological boundaries of the study cover the period of XVIII - the first half of XX century; geographical boundaries cover Europe, the United Kingdom and the United States. The relevance of the study is related to the relevance of popularizing science among students of technical specialties, as well as the development of soft skills through writing stories about scientific discoveries, fostering interest in reading fiction about science and technology. The purpose of the study was to find psychological and informational material that will affect the emotional sphere of the student's personality and motivate him to write and read works of art about research and innovation.

The ability to use research on the role of writers as promoters of science and technology depends on how we provide information about their works. In this regard, we offer a psychological technique to impress readers of scientific stories, i.e. the effect of "wow" as a combination of the factor "wow" and the halo effect. Stories about science affect different areas of human activity. They are used to address environmental, medical, political and other issues. The information material of the study confirms the following: if scientists and inventors do not demonstrate the consequences of their inventions and discoveries, it leads to erroneous assumptions, causes alarm in society and affects the mind of the individual. We studied the nature of writers' connection to science and sought answers to the question of whether writing works of art and the ability to do research could be equal aspects of an individual's abilities.

The results of the study prove that these abilities predominate in only one area of activity. We also support the view that writers can be impartial promoters of science and technology. However, we propose this idea for discussion because writers demonstrate more the ethical side of the interaction between science and the human mind than they disseminate scientific facts. The further development of the study will be related to the study of the influence of science fiction on consciousness, namely how science fiction informs the reader about the current state of the world and draws attention to the changes we must make as a species.

Key words: halo effect, "wow" factor, popularization of science and technology, consequences of inventions and discoveries.

\section{Тирон Олена Миколаївна,}

кандидат психологічних наук, доцент кафедри іноземних мов за професійним спілкуванням та гуманітарних дисииплін, Державний університет інфраструктури та технологій

\section{ВИКОРИСТАННЯ ХУДОЖНІХ ТВОРІВ ПИСЬМЕННИКІВ - ПОПУЛЯРИЗАТОРІВ НАУКИ І ТЕХНІКИ ДЛЯ РОЗВИТКУ М'ЯКИХ НАВИЧОК СТУ ДЕНТІВ ІНЖЕНЕРНИХ СПЕЦІАЛЬНОСТЕЙ}

\begin{abstract}
Письменники художньої літератури, які займаються наукою - феномен. Ми вивчали це явище для отримання нових можливостей розвитку м'яких навичок у студентів технічних спеціальностей та розвитку ідеї популяризаиії наукових досягнень. Хронологічні межі дослідження охоплюють період XVIII - периу половину ХХ століття; географічні межі охоплюють Свропу, Великобританію та США. Актуальність дослідження пов'язана з актуальністю завдання популяризації науки серед студентів технічних спечіальностей, а також розвитком м'яких навичок иляхом написання розповідей про наукові відкриття, вихованням інтересу до читання художньої літератури про науку і техніку. Мета дослідження полягала в пошуку психолого-інформаційного матеріалу, який матиме вплив на емочійну сферу особистості студента та мотивувати його до написання та читання художніх творів про наукові розробки та інновації. Можливість використовувати дослідження про роль письменників як популяризаторів науки і техніки залежить від того, як ми надаємо інформацію про їх твори. У зв'язку з цим ми пропонуємо психологічний прийом, щьоб вразити читачів наукових історій, тобто ефект «вау» як поєднання фактора «вау» та ефекту ореолу. Історії про науку впливають на різні сфери діяльності людей. Вони використовуються для вирішення екологічних, медичних, політичних та інших питань. Інформаційний матеріал дослідження підтверджує таке:
\end{abstract}


якщуо вчені та винахідники не демонструють наслідків своїх винаходів та відкриттів, ие призводить до помилкових припущень, викликає тривогу в суспільстві та впливає на розум особистості. Ми вивчали природу зв'язку письменників з наукою та шукали відповідь на питання, чи написання художніх творів та здатність займатися науковими дослідженнями можуть бути рівними сторонами здібностей особистості. Результати дослідження доводять, щзо ичі здібності переважають тільки в одній сфері діяльності. Також ми підтримуємо думку, ияо письменники можуть бути неупередженими популяризаторами науки та техніки. Але ми пропонуємо июю ідею для обговорення через те, шуо письменники більше демонструють етичну сторону взаємодії науки та людського розуму, ніж поширюють наукові факти. Подальший розвиток дослідження буде пов'язаний з вивчення впливу наукової фантастики на свідомість, а саме як наукова фантастика інформує читача про сучасний стан світу та привертає увагу до змін, які ми повинні зробити як вид.

Ключові слова: ефект ореолу; “вау» ефект; популярізачія науки та техніки; наслідки винаходів і відкриттів.

Introduction. Science and literature closely interacted. It is not just about the numerous textbooks, articles published by researchers in specialized journals, or the science fiction genre that is gaining more and more readers. Some scientists, in parallel with their main activities, try themselves in fiction. As well as the authors of fiction, they are often passionate about some kind of scientific field. All of the bellow ideas about the relationship between science and fiction show that it is reasonable to use this relationship to develop the social skills of technical students. The purpose of this article is to share the experience of using psychological and informational material to influence the emotional and motivational spheres of the student's personality.

To understand the role of fiction writers' contribution to the promotion of science and technology we refer to the philosophical interpretation of discovery, invention and creativity (Schickore, 2018), distinction between discovery and invention (Schwartz, 2021). The majority of recent philosophical studies of scientific discovery today focus on the act of generation of new ideas, scientific and fictional understanding (Park, 2020). Psychologists connect generating new ideas with cognitive mechanisms (Thagard \& Stewart, 2011).

Reputation of science in public imagination is closely connected with literature, cinema and mass media. The science gains its positive reputation through popularization with three main functions: 1) educational activity; 2) spread of real facts; 3) prevention of the development of pseudo-science (Seneko, 2018). Stories, rooted in scientific facts prevent danger of misinformation (Doberty \& Jordano, 2020), therefore social communication of researchers is an important characteristic of scientific activity (Okorokova \& Likhachova, 2020). Educational function of popularization of science implies positive changes in attitudes toward science. It can be achieved through reading science fiction (Manadue \& Jacups, 2018) and making science popular for broad audience through writing science stories (ElShafie, 2018). Educational activity of science popularization through creating stories of science (Niehouse, 2019) not only spread scientific facts but also raise ethical issues, such as, interaction of personality's mind and machines (Cross \& Ramsey, 2021), science and ethical values (Rodrigues, 2020), influence on consciousness (Melnychuk, 2017).

Research methods. The research is carried out on the edge of philosophy, psychology and history. We used archive method, which included biographical study and quality- quantity analysis of the pieces of art.

The purpose of the study was to get insight into the role of fiction writers' pieces of art in popularization of innovations and technologies, which will help to educate creativity in STEM students. The creative writing will help to share experiences, generate new ideas, strengthen motivation, educate empathy, and clear up moral issues.

The research tasks were to find out:

1. What is the nature of writers' connection to science?

2. What is a hobby - writing or inventing. Can these two sides of personality's ability be equal?

3. Can writers be unprejudiced popularizers of science and technology?

Writers- scientists or inventors is a phenomenon. We studied this phenomenon to obtain benefits for education technical students and develop ideas of popularization scientific achievements among the audience. The chronological boundaries of the work cover the period of the XVIII- the first half of XX century; geographical boundaries cover Europe, the UK and the USA. In history, this period is recognized by mild transformation from fantasy to science fiction in the context of connection to science coverage. In our search, we used the following criteria:

1. Famous writers who predicted inventions;

2. Famous writers who realized their inventions;

3. Well-known writers who had professions connected with science and technologies;

4. Well-known scientists who wrote some fiction works;

5. People of engineer professions who attempted in writing fiction.

In the search of the research material, we used different encyclopedias. Few writers and scientists suited the criteria of the search. Nevertheless, the coverage of issues of interaction of fiction and science is relevant today. We can find appeals to the scientist to write essays that will give the audience the information about science

Наукові записки Національного університету «Острозька академія», серія «Психологія», № 13, червень, 2021 р. 
development and will generate new creative ideas. We chose 16 writers (table 1) for further analyses of their biographies and pieces of their art.

Table 1

List of writers in chronological order whose activity is connected with science, inventions and technology

\begin{tabular}{|c|c|c|c|c|}
\hline & Name & Years & Field of Interests & Connection with science and technologies \\
\hline 1. & $\begin{array}{l}\text { Johann Wolfgang } \\
\text { Goethe }\end{array}$ & $1749-1832$ & $\begin{array}{l}\text { German poet, playwright, } \\
\text { novelist, scientist }\end{array}$ & Theory of color perception. \\
\hline 2. & Marry Shelley & $1797-1851$ & English writer & Description of a laboratory experiment. \\
\hline 3. & Jules Verne & $1828-1905$ & French writer & Predictions of military cases. \\
\hline 4. & Lewis Carroll & $1832-1898$ & $\begin{array}{l}\text { English writer, } \\
\text { mathematician, inventor }\end{array}$ & Mathematical theories \\
\hline 5. & $\begin{array}{l}\text { Mark Twain } \\
\text { (Samuel Clemens) }\end{array}$ & $1835-1910$ & $\begin{array}{l}\text { American writer } \\
\text { inventor }\end{array}$ & Practical inventions. \\
\hline 6. & Hugo Guernsbeck & 1884-1967 & $\begin{array}{l}\text { American inventor, writer, } \\
\text { editor, and magazine publisher }\end{array}$ & $\begin{array}{l}\text { He held } 80 \text { patents. } \\
\text { Predictions of television, videophone, } \\
\text { transcontinental air service, solar energy in } \\
\text { everyday use. }\end{array}$ \\
\hline 7. & Herbert Wells & $1866-1946$ & $\begin{array}{l}\text { English novelist, journalist, } \\
\text { sociologist, and historian }\end{array}$ & $\begin{array}{l}\text { He acquired a reputation as a prophet of the } \\
\text { future, foresaw certain developments in the } \\
\text { military use of aircraft. }\end{array}$ \\
\hline 8. & Vladimir Nabokov & $1899-1977$ & $\begin{array}{l}\text { Russian- American writer, } \\
\text { Entomologist. }\end{array}$ & Science of Lepidoptera \\
\hline 9. & Saint-Exupery & $1900-1944$ & $\begin{array}{l}\text { a pilot of civil aviation } \\
\text { a French writer }\end{array}$ & Aero-engineering \\
\hline 10. & Robert Heinlein & 1907-1988 & $\begin{array}{l}\text { American science-fiction } \\
\text { author, aeronautical engineer, } \\
\text { and Naval officer }\end{array}$ & $\begin{array}{l}\text { Aeronautical engineering, wrote a book about } \\
\text { epidemic. }\end{array}$ \\
\hline 11. & Ronald Dahl & 1916-1990 & $\begin{array}{l}\text { British writer, a popular } \\
\text { author of children's books }\end{array}$ & $\begin{array}{l}\text { Dystopian future imagining worldwide nuclear } \\
\text { war. }\end{array}$ \\
\hline 12. & Arthur Clarke & $1917-2008$ & $\begin{array}{l}\text { English science-fiction, } \\
\text { nonfiction writer, inventor }\end{array}$ & Satellite communication. \\
\hline 13. & Isaac Asimov & $1920-1992$ & $\begin{array}{l}\text { professor of biochemistry; } \\
\text { a science fiction writer }\end{array}$ & Biochemistry. \\
\hline 14. & Renat Polevoy & $1927-2007$ & $\begin{array}{l}\text { writer, engineer - inventor, } \\
\text { local historian }\end{array}$ & Engineering. \\
\hline 15. & Gene Wolfe & $1931-2019$ & $\begin{array}{l}\text { American science fiction and } \\
\text { fantasy writer, } \\
\text { industrial engineer }\end{array}$ & $\begin{array}{l}\text { Industrial engineer who helped devise the } \\
\text { cooking process for Pringles. }\end{array}$ \\
\hline 16. & Roald Hoffmann & 1937 & $\begin{array}{l}\text { a scientist, a writer } \\
\text { (born in Ukraine) }\end{array}$ & The Nobel Prize winner in Chemistry. \\
\hline
\end{tabular}

Results and discussion. What is the nature of writers' connection to science? To analyze writers' biographies and inspirations we use the research plan offered by Baverstock \& Steinitz (2019), which includes 1) childhood influences; 2) motivation, barriers, benefits of writing; 3) the psychological profile.

Qualitative analysis of the chosen writers' biographies has shown that they were ideas personalities, but the details of their scientific descriptions in their pieces of art were often wrong. They had great interest in the development of science and technologies, they learned information from reliable sources of scientific information, and it helped the writers to describe inventions and innovations in an accurate way.

The sources of their ideas were:

- circumstances of their private lives;

- - level of availability of scientific information to the audience;

- political situation in their country and in the world and attitudes in the society;

- creativity of the writer;

- balance of intuition and scientific thinking.

While speaking about predictions of scientific discoveries by writers we speak about a combination of intuition and scientific predictions. Scientific predictions are based on scientific knowledge, which includes scientific theories, information in mass media available for the audience. Intuition predictions in the writers' works are connected with different components of writers' talent: vividness, imagination, creativity. Some scientists connect these qualities with the ability to make inventions. Creativity is an aspect of human thinking. 
Creativity involves the ability to produce a work that is original and leads to new inventions and solutions. Therefore, creativity plays a crucial role in human thought, being involved in different activities. Researchers show a positive correlation between the vividness score and the practicality score of inventions (Palmiero et al., 2011).

What is a hobby - writing or inventing. Can these two sides of a personality's ability be equal?

If we speak about popularity or significance, we see only one side fully realized - a popular writer or an outstanding inventor or scientist. Only one side of a person's ability recognized to be successful.

Can writers be unprejudiced popularizers of science and technology?

We offer for the discussion the idea that writers can be unprejudiced popularizers of science. Writers more show the ethical side of the interaction of science and human mind than spread scientific facts. The possibility to use the research about writers' role as popularizers of science and technology depends on how we give information about writers' pieces of art. We offer to influence personalities' emotions, impress them as we show in the pictures above (fig.1-3). The mentioned inventions and developed theories may be not outstanding for science and society, but the fact that they were made by famous writers impress the audience.

We can shuffle all chosen writers for research to get a bright wow effect to influence the audience mind with the purpose of popularization of science and technology, realizing educational function among STEM students.

All this information can have wow effect on the reader. Wow effect is a combination of wow factor and halo effect. Wow factor is a quality or feature of something that makes people feel great excitement or admiration. Halo effect is the positive opinion that someone has of a person, product, company, etc. as a whole, which is based on an earlier opinion of one particular quality or feature (https://dictionary.cambridge.org/ru). In our research, it is information that impresses the reader and quickly remembered. We show three combinations: 1) writers who predicted inventions; 2) writers who made inventions; 3) writers who developed scientific theories. The combinations may be different depending on the target audience, such as romantics of science or science fiction and engineering.

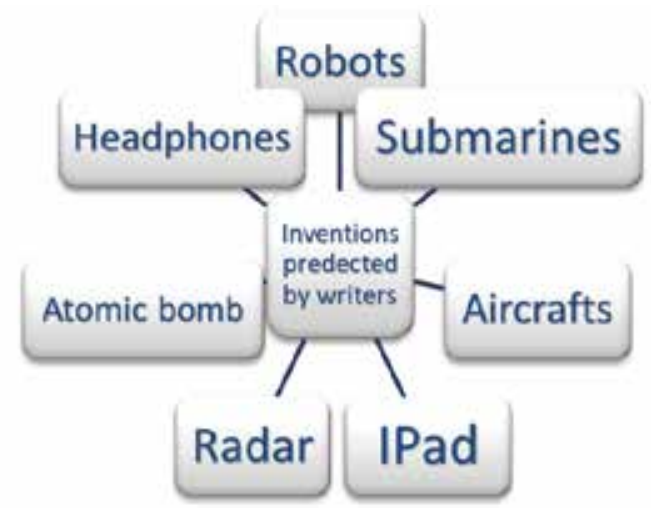

Fig.1. Information to influence readers' perception. Inventions predicted by writers.

We see the increasing interest of the writers to the military cases. 1) In the late nineteenth century, Vern began to pay more attention to assumptions, warnings, increasingly turning to the subject of inventions as weapons. Therefore, he depicts a giant cannon that sends shells with poisonous substances for hundreds of kilometers, and a super projectile "Fulgurator of Rock", the explosion of which leaves a crater and destroys buildings in a huge radius around. Verne in his work "Twenty Thousand Leagues under the Seas: A World Tour Underwater" (1869) introduced readers to the submarine "Nautilus" and a hypothesis about the role of submarines in the military case. 2) Although Heinlein did not predict the explosive nature of nuclear weapons, he accurately wrote that toxic radiation would be the primary cause of death when using atomic weaponry.3) In his fantasy story, "The Land of Battleships", Wells described a battle scene involving a modern tank-like mechanism in the form of a giant clumsy insect. The story was completed in 1903, and the first tank was assembled in 1916. Another military "invention" of Wells - atomic bombs. In "The Liberated World of 1914", he described the work on the principle of atomic fission (Nicholson,2021). Wells's work also demonstrates science fiction's critical potential (Wegner, 2020).

Predictions of the XX century are mostly connected with IT technologies.

1) Back in 1968, Clarke in a series of works "Space Odyssey" presented his characters with the so-called "Newspad" - tablets, the properties of which today have an iPad. However, according to Clark, this tablet was intended only for viewing newspapers. The same writer foresaw another invention of humanity in his novel "City and Stars" (1956) - games in virtual reality. The first video games were launched only 2 years later.2) But back in 1911, the American writer and publisher Guernsbeck in the novel "Ralph 124C 41+" described 
the video chat, the functions of which are now available in many programs and social networks. In the same novel, Gernsbeck presented to the public the idea of the device capable of determining the location of an object depending on its radio waves - radar.

When these predictions were later realized, the writers got the halo of mystery. They became successful popularizers of science and technologies.

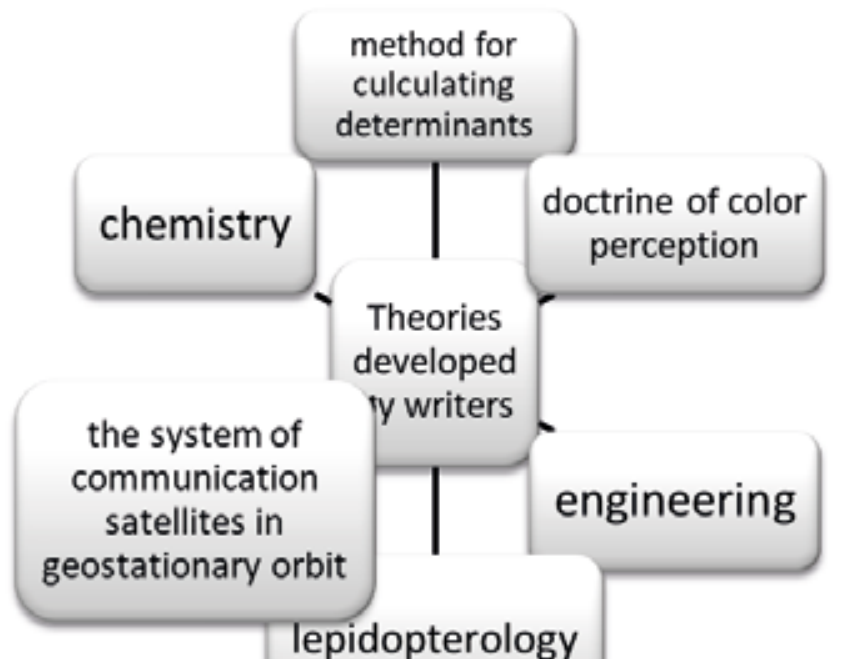

Fig.2. Information to influence readers' perception. Famous writers who realized their inventions

Most of the things without which we cannot imagine our world today were once just fiction. Moreover, most interestingly, many of them were invented by writers, not scientists. An atomic bomb, a submarine or a smartphone. Moreover, what other technical achievements of the modern world have writers forgave? Heinlein invented a bed that used water instead of springs. Heinlein had first described a waterbed in his 1942 novel "Beyond This Horizon", and then in the Hugo award-winning "Double Star" in 1956. Dahl is famous for his "Charlie and the Chocolate Factory". When his son was hospitalized after a car accident in 1960, the writer worked with researchers to develop a valve that could drain fluid build-up from the brain. Carroll invented a postage case made of several pockets and figured out how to write in the darkness. In 1891, he invented the nyctograph - a cardboard card with 16 square holes, in which the writer wrote whole sentences in a specially created font. He also suggested using the method of writing for blind people. Clemens (Mark Twain) invented a calendar that does not specify the days of the week and can be used forever but did not patent it. Twain developed a scrapbook (self-pasting scrapbook) where the user only has to moisten the glue in order to make the page functional. N. Tesla often spent a lot of time in the lab with Mark Twain, where they communicated and tested all kinds of scientific ideas in practice. That is why Twain was acquainted with Tesla's ideas, which in some way influenced his outlook. Gernsback holds 80 patents. His first patent was a new method for manufacturing dry-cell batteries. Among his inventions are a combined electric hairbrush and comb (1912); an ear cushion (1927); and a hydraulic fishery (1955).. His novel "Ralph 124C 41+," is considered a classic for its predictions of television, videophone, transcontinental air service, solar energy in everyday use, and other inventions that became common in the future. Wolfe was a mechanical engineer who worked with Procter \& Gamble. During his employment, Wolfe devised the unique, shingle-shaped Pringles chips to be fried and then dumped into their cylindrical packaging. His best-known and most highly regarded work is the multi-volume novel "The Book of the New Sun".

Goethe developed the theory of colour perception. The writer's conclusions turned out to be erroneous. However, his work became a significant help for those who later studied the theory of color perception. Goethe was also the first to find the intermaxillary bone in humans. In addition, his research gave rise to the science of glaciers and phytomorphology. Clark is a famous science fiction writer who proposed a practical concept of satellite communication in a paper titled "Extra-Terrestrial Relays: Can Rocket Stations Give World-wide Radio Coverage?" published in 1945. He proposed that a satellite at an altitude of 35,786 km (22,236 miles) above Earth's surface would be moving at the same speed as Earth's rotation. At this altitude, the satellite would remain in a fixed position relative to a point on Earth. This orbit, now called a "geostationary orbit," is ideal for satellite communications (Labrador, 2020). As a science fiction writer, he was especially attracted to the field of futurology. In his artistic work, Clark relied on the very real achievements of science, allowing himself only a minimum of fantastic assumptions (Gregersen, 2020). Carrol was a professor of mathematics recognized for his outstanding ability in the exact sciences. He is the author of the method for calculating determinants known as Dodgson Condensation. 


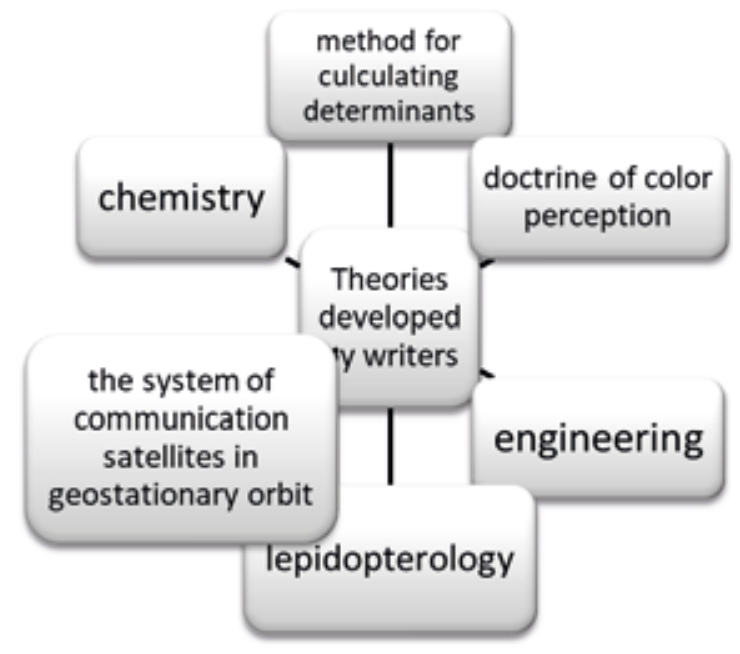

Fig.3. Information to influence readers' perception. Theories developed by fiction writers.

Nabokov along with the literature, attracted to lepidopterology - Nabokov studied insects (butterflies). On his account is a description of several previously unknown to science species of Lepidoptera, as well as a number of scientific articles in thematic journals. It is also reflected in Nabokov's books. Butterflies are found more than 500 times in his works. Conversely, entomologists have named more than 20 new species in honor of Nabokov's characters. The image of this writer is shrouded in a halo of romance. He is known as an aviator and is popular as a romantic writer. Saint-Exupery's literary biography began with the short story "The Pilot" published in 1926, "The Planet of the People" published in 1939. The French Academy awarded the book the Grand Prize for Novel. Exupery wrote his last book, The Little Prince, in 1942 in New York. By genre, it is a philosophical fairy tale, where the author embodies his own dream of a natural attitude to things and people. Asimov is an American author and biochemist, a highly successful and prolific writer of science fiction and of science books for laypersons. He wrote or edited about 500 volumes, the most famous are robot series. His writing explored various topics in chemistry, physics, and biology (Gregersen, 2021). Shelley wrote the Gothic novel "Frankenstein; or, The Modern Prometheus" (1818), which is considered an early example of science fiction. Mary Shelley did not work in science, but her literature work is still studied by scientists because of its influence on people's minds. Frankenstein can help students reflect on the personal and social limits of science, the connection between curiosity and scientific progress, and scientists' responsibilities (Cambra-Badii et al., 2021).

Special place in our research belongs to Hoffmann (born 1937) because he is more known as a scientist than as a writer. He is the Nobel Prize winner in Chemistry. He was born in Zolochiv, Lviv region of Ukraine. In 1981, Hoffmann received the Nobel Prize in Chemistry, which he shared with Kenichi Fukui - a Japanese chemist. Roald Hoffmann wrote about chemistry's relationship to philosophy, literature, and the arts, the nature of chemical reasoning, the role of symbolism and writing in science, and the relationship between art, craft, and science. He is the author of "The Metamic State" (1987); "Gaps and Verges" (1990); "Memory Effects" (1999); "Soliton" (2002); "Catalista: Poemas Escogidos" (2002), "Roald Hoffmann. Izbrannie Stichotvorenia" (2010). He has also co-written a play entitled "Oxygen" (Mishalov, 2020, p.216].

Renat Polevoy (1927), writer, engineer - inventor, philanthropist and local historian. Author of more than 90 inventions and 72 scientific articles. He was born in Moscow, where his father worked at the time. While serving his sentence in Kolyma, he befriended Ukrainian prisoners who were members of the OUN and UPA. He wrote and published the books "Kuban Ukraine", "Kobzars in my life" and "Memories". Polevoy became friends with Ivan Honchar, whom he helped financially. He was a member of the Ukrainian Helsinki Union. Its technologies for the production of high-fine basalt fiber were used in the military industry and implemented in production.

Karatsupa and Levchenko (2011) described Ukrainian fantasy fiction of the studied period. The authors presented the results of research into 19th and 20th century fantasy fiction in the Ukrainian language and state some writers as the most prominent Ukrainian writers working in the fantasy genre. The scientists describe the biography of M. Dashkiev (1921-1976) who got the education of a physicist and worked as a teacher. In his writings, Dashkiev promotes new achievements and trends in microbiology and medicine.

One of the functions of science popularization is to prevent the development of pseudo-scientific assumptions. Fears arouse common people when scientists do not show all possible consequences of their inventions and discoveries. So it is with the robots (Cross et al., 2019), space (Gillon, 2020), etc. People become anxious, make horrible assumptions. In fiction, quasi-reality dominates reality, the emotion of fear becomes the basic emotion, 
a fundamental property of which will trigger the instinct of self-preservation human personality in ensuring its viability in the fiction world (Melnychuk, 2017). Here social panic may appear in society, and then, when a real disaster occurs, people speak about writers' predictions. This is just the case we are having now with the pandemic of Covid-19. Since the global outbreak of COVID-19, internet users' interest in pieces of art about pandemics has increased.

Lack of information and panic lead to the emergence of a wide range of assumptions on the negative consequences of future events. Panic forms an unstable, unpredictable state of the human psyche, caused by informational influence, which entails a number of inappropriate actions, and at the heart of this phenomenon is information psychological turbulence (Kabantseva \& Panchenko, 2020).

Stories about science influence different spheres of people's activity. They are used to solve problems in ecology (Acara \& Caglara, 2014), in medicine (King, 2013; Snaith, 2017), in political sciences (Wilcox, 2017), etc.

Further development of the research will be connected with science fiction and consciousness, which informs the reader about the current state of the world and draws awareness to the changes that we must make as a species. Science fiction shows how to respond to the challenges engineers face today: to conceive ethically, to prioritize societal issues, and to be creative (Michaud, 2020).

Conclusion. Few writers and scientists suited the criteria of the search - exhibit a combination of science and fiction writing activities. This study is an appeal to the scientist to write essays that will give the audience information about science development and generate new creative ideas. Qualitative analyses of the chosen 16 writers' biographies and pieces of their art have shown that they were ideas personalities but often their descriptions were erroneous. The sources of their ideas are circumstances of their private lives; level of availability of scientific information to the audience; political situation in their country and in the world and attitudes in the society; the creativity of the writer; balance of intuition and scientific thinking. The research proves that only one side of the person's ability is fully realized - an outstanding writer or an outstanding scientist. Only one side of a person's ability recognized to be successful. The study shows that fiction writers can be unprejudiced popularizers of science and technology realizing different functions of such popularization.

\section{References:}

1. Acara, N., Caglara, S. (2014). From Media as the Producer of False Consciousness to Ecological Media. Procedia - Social and Behavioral Sciences 155 pp. $299-303$

2. Baverstock, A., Steinitz, J. (2019). What Makes a Writer? How Do Early Influences Shape, and Working Habits Develop, Those Who Write? Pub Res Q 35, pp.327-35. doi.org/10.1007/s12109-019-09660-w

3. Cambra-Badii, I., Guardiola, E., Baños, J.-E. (2021). Frankenstein; or, the modern Prometheus: a classic novel to stimulate the analysis of complex contemporary issues in biomedical sciences. BMC Medical Ethics, 22 (1). doi:10.1186/s12910-021-00586-7

4. Cross, E.S., Ramsey, R. (2021). Mind Meets Machine: Towards a Cognitive Science of Human-Machine Interactions. Trends in Cognitive Sciences, Volume 25, Issue 3, pp. 200-212

5. Cross ES, Hortensius R, Wykowska A. (2019). From social brains to socialrobots: applying neurocognitive insights tohuman-robot interaction. Phil. Trans. R. Soc. B374: 20180024. doi.org/10.1098/rstb.2018.0024

6. Doberty J., Jordano J. (2020). What we may learn - and need - from pandemic fiction. Philosophy, Ethics, and Humanities in Medicine, 15:4.doi.org/10.1186/s13010-020-00089-0

7. ElShafie, S. J.(2018). Making Science Meaningful for Broad Audiences through Stories. Integrative and Comparative Biology, volume 58, №6, pp.1213-1223.

8. Gregersen, E. (2020). "Arthur C. Clarke". Encyclopedia Britannica. https://www.britannica.com/biography/ Arthur-C-Clarke.

9. Gregersen, E. (2021, January 1). Isaac Asimov. Encyclopedia Britannica. https://www.britannica.com/ biography/Isaac-Asimov

10. Gillon, M.(2020). Life under another Sun: From Science Fiction to Science. European Review,Volume 28, Issue 1, pp. 18-39

11. Kabantseva, A., Panchenko O.(2020). Panica yak psykhologichnyi factor informatsiynoi nebezpeky osobystosti. [ Panic as a psychological factor of information safety of a personality. Psykhologiya i osobystist. [Psychology and Personality], 2 (18) 10 [in Ukrainian].

12. Karatsupa, V., Levchenko, O. (2011) Ukrainian Fantasy Fiction of the 19th - 20th centyriies in periodicals and books. Visnyk of the Lviv University. Series Bibliol. Libr. Stud. Inform. Techn. Is. 6. pp. 215-243[in Ukrainian].

13. King, H. (2013). Fighting Through Fiction. Cult Med Psychiatry 37, 686-693. doi.org/10.1007/s11013-0139347-6

14. Labrador, V.(2020). "Satellite communication". Encyclopedia Britannica. https://www.britannica.com/ technology/satellite-communication.

15. Menadue, C.B., Cheer, K.D. (2017). Human Culture and Science Fiction: A Review of the Literature, 19802016. Sage Open, 1-15. doi.org/10.1177/2158244017723690

16. Menadue, C.B., Jacups, S. (2018). Who Reads Science Fiction and Fantasy, and How Do They Feel About Science? Preliminary Findings From an Online Survey. Sage Open,1-12. doi.org/10.1177/2158244018780946 
17. Michaud, T.(Ed.). (2020). Using Science Fiction in Engineering Education. doi.org/10.1002/9781119779599. $\operatorname{ch} 2$

18. Melnychuk, M. (2017). Problema vplyvu tvoriv kinomystetsva na cvidomist ta pidsvidomist osobystosti gliadacha. [ Problem of the influence of the works of cinema art on the consciousness and sub-concsiousness of the viewer's personality]. Psykhologiya I Osobystist [Psychology and Personality], 1(11), 268-278. http://doi.org/10.5281/ zenodo.260216[in Ukrainian].

19. Mishalov, D.V. (2020). Pid znakom Nobelia: lidery naukovogo progresu abo rozdumy vchenogo - biokhimika ji imunologa pro rozvytok i znachennia nauk pro zhyttia [Under the sign of Nobel: leaders of scientific progress or speculations of scientist-biochemists and imunologist about the development and meaning of sciences about life] editor S.V. Komisarenko. Kyiv. FOP Mishalov, 240 p.

20. Nicholson, N. (2021). "H.G. Wells". Encyclopedia Britannica, https://www.britannica.com/biography/H-GWells.

21. Niehouse, A. (2019). Creating stories of science. International Journal of Innovation in Science and Mathematics Education, 27(6), pp. 45-49.

22. Okorokova, V.,Likhachova, O. (2020). Formation components of technical science in Ukraine in the 60-70s of the XIX century. Istorija nauky I tekhniky, tom 10, vypusk 2. [History of science and technology, 2020, vol. 10, issue 2].

23. Palmiero, M., Cardi, V., and Olivetti Belardinelli, M. (2011). The role of vividness of visual mental imagery on different dimensions of creativity. Creat. Res. J. 23, 372-375. doi: 10.1080/10400419.2011.621857

24. Park, S. (2020). Scientific Understanding, Fictional Understanding, and Scientific Progress. Journal for General Philosophy of Science, Volume 51, Issue 1, pp. 173-184

25. Palmiero, M., Nori, R., Aloisi, V., Ferrara, M.,Piccardi, L.(2015). Domain- Specificity of Creativity: A Study on the Relationship between Visual Creativity and Visual Mental Imagery. Frontiers in Psychology 6.1870. doi: 10.3389/fpsyg.2015.01870

26. Rodriguez, M.G. (2020). Ethical values and their relationship with science and technology. A proposal for working in the classroom. HASER. Revista Internacional de Filosofia Aplicada, 11, pp. 125-161

27. Schickore, J. (2018). "Scientific Discovery", The Stanford Encyclopedia of Philosophy, Edward N. Zalta(ed.), https://plato.stanford.edu/archives/sum2018/entries/scientific-discovery

28. Schwartz, B. (2021). Idea Technology and Ideology. Cult Med Psychiatry. doi.org/10.1007/s11013-02109712-x

29. Senenko, A. (2018). Populiarizatsiya dosiagnen naukovtsiv akademiyi u mediya-prostori. [Popularization of the scientists' achievements in media-space]. Visnyk NAN Ukrainy, № 5 pp.56-59.[in Ukrainian]

30. Snaith, H. (2017). dystopia, gerontology and the writing of Margaret Atwood. Fem Rev 116, pp. 118-132 doi. org/10.1057/s41305-017-0068-5

31. Thagard, P. and Stewart, T. C., 2011, "The AHA! Experience: Creativity Through Emergent Binding in Neural Networks", Cognitive Science, 35: 1-33.

32. Wilcox, L. (2017). drones, swarms and becoming-insect: feminist utopias and posthuman politics. Fem Rev 116, 25-45. https://doi.org/10.1057/s41305-017-0071-x

33. Wegner, P.E. (2020). Science Fiction/Fantasy. Wiley Online Library. https://doi.org/10.1002/9781444337815. wbeotns001 